\title{
Resazurin-based assay for screening bacteria for radiation sensitivity
}

\author{
Deborah A Hudman and Neil J Sargentini
}

\begin{abstract}
We report a simple and efficient colorimetric method to screen large numbers of bacterial strains for UV- and X-radiation sensitivity. We used reference radiation-sensitive and control strains of Escherichia coli K-12 to compare our colorimetric method to a standard clonogenic plating method. Our colorimetric method was as accurate as the standard method and was superior in terms of savings in supplies and man-hours.
\end{abstract}

Keywords: Resazurin, Radiation-sensitivity assay, High throughput, X-radiation, UV radiation, Escherichia coli

\section{Background}

Studies on radiation-sensitive mutants of bacteria, e.g., Escherichia coli, have been invaluable in elucidating mechanisms of DNA repair (Augusto-Pinto et al. 2003; Friedberg et al. 2006). However, it is common that one needs to screen, in time-consuming and expensive fashion, large numbers of strains to find or quantitate a desired phenotype. With this goal, we developed a resazurin-based assay using 96-well microtiter plates to reduce the very significant time and expense normally associated with traditional clonogenic (plating) assays for radiation sensitivity. We believe our new assay is sensitive, rapid, robust and economical, and it should facilitate any studies where the goal is to quickly and economically separate strains of differing radiation sensitivities, e.g., mapping or transformation studies involving hundreds of strains, or studies where large numbers of agents and concentrations would be tested for their impact on radiation survival. Conversely, our assay can be used to test for factors or mutant genotypes that might produce radiation resistance. The value of our new assay is directly proportional to number of strains or conditions that need to be tested efficiently and at low cost. Although we describe our assay using E. coli, this assay should be easily modifiable for use with other bacteria or higher organisms.

Resazurin is a purple, non-toxic, oxidation-reduction indicator that becomes pink when reduced to resorufin

\footnotetext{
* Correspondence: nsargentini@atsu.edu

Department of Microbiology and Immunology, AT Still University of Health Sciences, Kirksville, MO, USA
}

by cellular oxidoreductases (Vega-Avila and Pugsley 2011). The concentration of viable cells in a suspension containing resazurin directly determines the time-point for a visible conversion from purple to a pink color (Vega-Avila and Pugsley 2011). Resazurin reduction tests have been used for decades to demonstrate bacterial and yeast contamination of milk, and to determine chemical cytotoxicity and minimum inhibitory concentration values for antibiotics (Bigalke 1984; Drummond and Waigh 2000; McNicholl et al. 2006; Sarker et al. 2007). Resazurin has been used in a few screening studies for radiation sensitivity of mammalian cells (Gil et al. 2011; Seideman et al. 2010), however, to our knowledge, a resazurin-based assay for use in screening bacterial strains for radiation sensitivity has not been described. As in other resazurin-based studies, the readout in our assay is colorimetric and the rate of color change is directly proportional to the number of viable cells in the initial suspension. Compared to a DNA repair proficient, parental, control strain, the time-point for color conversion is extended in suspensions of cells that are more sensitive to radiation and have relatively fewer viable cells in the irradiated cell suspension. We developed this technique so that one could visually scan hundreds of microtiter wells quickly. We show that the visual results can be quantified with a microplate reader, but this is not a requirement. Visual inspection will suffice to easily identify strains that are more sensitive to radiation, i.e., their wells show more purple or less pink color than the control strain after a set time of incubation. \\ Springer}


We report on the reliability of our colorimetric assay by testing (i) the radiation dosimetry among the 96 wells of a microtiter plate, (ii) the resazurin color change for reference radiation-sensitive and -resistant strains of E. coli after both UV- and X-irradiation, and (iii) the sensitivity of our colorimetric assay (an indirect measure of cell survival) in comparison with a clonogenic assay (a more traditional and direct measure of cell survival) for differentiating a set of reference E. coli strains based on their radiation sensitivities. We also report an estimate of the cost savings in using the colorimetric assay vs. the clonogenic assay.

\section{Results and discussion}

First, we determined the well-to-well variation in X- and UV-radiation dosimetry in our 96-well microtiter plates. We used chemical dosimetry to determine the mean $\mathrm{X}$ radiation dose rate over 288 wells $(3 \times 96)$, which was $17.96 \pm 0.02 \mathrm{~Gy} \mathrm{~min}^{-1}$. The well-to-well variation of chemical dosimeter readings, which are directly proportional to $\mathrm{X}$-ray dose rates, is shown in Figure 1A. Although, we measured our UV radiation dose rate at $1.42 \mathrm{~J} \mathrm{~m}^{-2} \mathrm{~s}^{-1}$ for the entire irradiated field, we used our resazurin-based bioassay to assess the mean effect of UV radiation on the cell suspensions in 576 wells $(6 \times 96)$, and this was $0.77 \pm$ $0.02 \mathrm{~A}_{492}$ units. The well-to-well variation in UV-radiation dose rate is represented by the $\mathrm{A}_{492}$ values shown in Figure 1B.

Second, we visually assessed the color change after UVor X-irradiation for 17 E. coli $\mathrm{K}-12$ isogenic reference strains (Table 1), the DNA repair proficient, parental, control strain, SR749, and 16 others with single, radiationsensitizing mutations at the $\operatorname{lex} A, \operatorname{pol} A, \operatorname{rad} A, \operatorname{rad} C, \operatorname{rec} A$,
Table 1 Escherichia coli K-12 strains used in this study ${ }^{a}$

\begin{tabular}{lll}
\hline Strains & Genotype & Source, Reference \\
\hline SR749 & parental, control & $\begin{array}{l}\text { AB1157, E. coli Genetic } \\
\text { Stock Center }\end{array}$ \\
SR1159 & recB21 & NJS Lab strain \\
SR1165 & umuC122::Tn5 & NJS Lab strain \\
SR1187 & radC102 & I Felszenswalb \\
SR1252 & polA5 & NJS Lab strain \\
SR1277 & uvrD254::Tn5 & NJS Lab strain \\
SR1279 & lexA101 & NJS Lab strain \\
SR1467 & recA sr1301::Tn10 & NJS Lab strain \\
SR1553 & recN262 & NJS Lab strain \\
SR1643 & recC22 & NJS Lab strain \\
SR1663 & recJ284::Tn10 & NJS Lab strain \\
SR2384 & ruvA59::Tn10 & NJS Lab strain \\
SR2385 & ruvB60::Tn10 & NJS Lab strain \\
SR2603 & DruvC64::kan & RG Lloyd \\
SR2604 & recG258::kan & RG Lloyd \\
SR2666 & recF332::Tn3 & NJS Lab strain \\
SR2877 & radA110::kan & NJS Lab strain \\
\hline
\end{tabular}

${ }^{a}$ All strains were derived from the DNA repair proficient E. coli K-12 AB1157 strain (SR749), and carry the following mutations: $\operatorname{argE3(oc),~hisG4(oc),~leuB6~}$ (amIII), $\Delta$ (gpt-proA)62, thr-1, thi-1, ara-14, galK2, lacY1, mtl-1, xyl-5, tsx-33, rfbD1, mgl-51, rpsL31, supE44(amSull), rac, $\mathrm{F}^{-}, \lambda^{-}$. Genetic nomenclature has been described (Berlyn 1998).

$\operatorname{rec} B, \operatorname{rec} C, \operatorname{recF}, \operatorname{rec} G, \operatorname{rec}$, $\operatorname{rec} N, \operatorname{ruv} A, \operatorname{ruv} B, u m u C, u v r D$, or $r u v C$ genes. During these experiments, we consistently were able to visually differentiate the 16 "radiationsensitive" strains compared to the parental control strain based on culture color. An example of the color differential is shown in Figure 2.
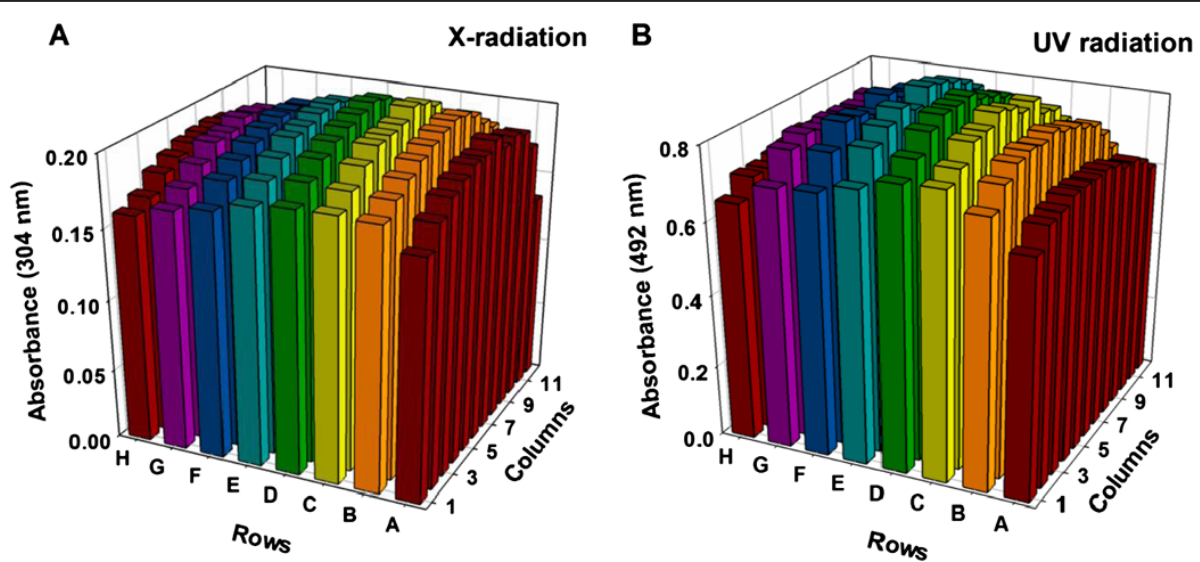

Figure $1 \mathrm{X}$ - and UV-radiation dose rates within the $\mathbf{9 6}$ wells of a microtiter plate. (A) The absorbance within each well was determined at $304 \mathrm{~nm}\left(\mathrm{~A}_{304}\right)$ in triplicate experiments using a chemical dosimeter and plotted. The rows (letters) and column (numbers) in the graph associate data with individual wells in the microtiter plate. The average dose rate for $160 \mathrm{kV}$ X-rays was determined from $\left(\Delta \mathrm{A}_{304}\right)\left(280 \mathrm{~Gy} \mathrm{~min}^{-1}\right)$ to be $17.96 \mathrm{~Gy} / \mathrm{min}(\mathrm{sd}=0.02)$, and plates received a dose of $54 \mathrm{~Gy}$. (B) $\mathrm{A}_{492}$ values for resazurin absorbance (indicating the cellular metabolic activity

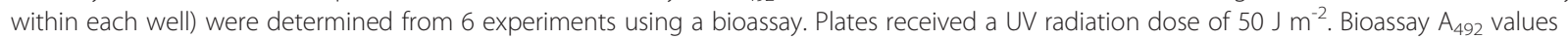
were averaged and plotted. The mean value over 96 wells was $0.77(s d=0.02) A_{492}$ units. 


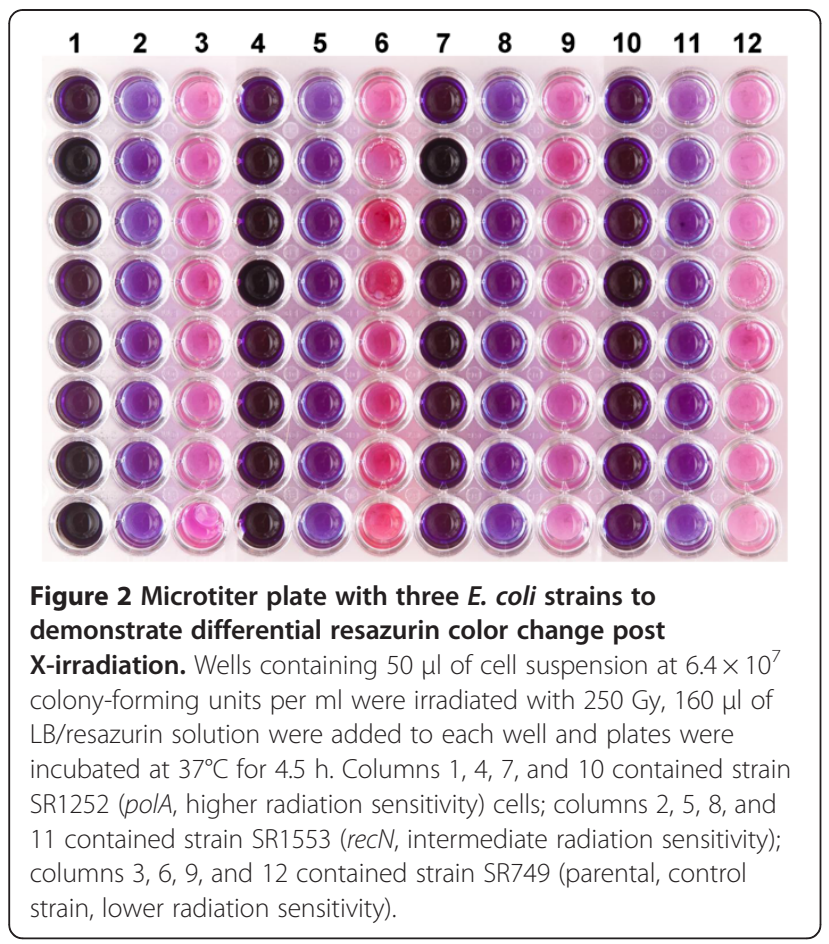

The third test of the resazurin-based assay involved plotting the radiation sensitivity data (direct measure) for our set of 17 reference E. coli strains against resazurin/ resorufin absorbance values (indirect measure) in Figures $3 \mathrm{~A}$ and $3 \mathrm{~B}$. Cell surviving fractions of UV- and $\mathrm{X}$-irradiated cells were determined using a clonogenic assay. Irradiated or non-irradiated cells were plated onto duplicate LB agar plates. After overnight incubation at $37^{\circ} \mathrm{C}$, colonies were counted and cell-surviving fractions were calculated. Resazurin/resorufin absorbance values $\left(\mathrm{A}_{492}\right)$ were attained from the colorimetric assay plates using a microplate reader. The results of the colorimetric and clonogenic assays are shown in Table 2, and indicate a similar ability of each assay to differentiate radiationsensitive strains from the parental, control strain. Figures $3 \mathrm{~A}$ and $3 \mathrm{~B}$ confirm that irradiated strains showing lower surviving fractions (i.e., more sensitive to radiation than the parental, control strain) also showed higher $\mathrm{A}_{492}$ values (i.e., their irradiated cell suspensions showed less metabolic activity than the parental, control strain). We plotted the mean surviving fraction and $\mathrm{A}_{492}$ data ( \pm 2 sem) for the parental, control strain (WT) to produce a gray-shaded box in the upper left-hand corner of each graph. Mean \pm sd data for reference test strains that did

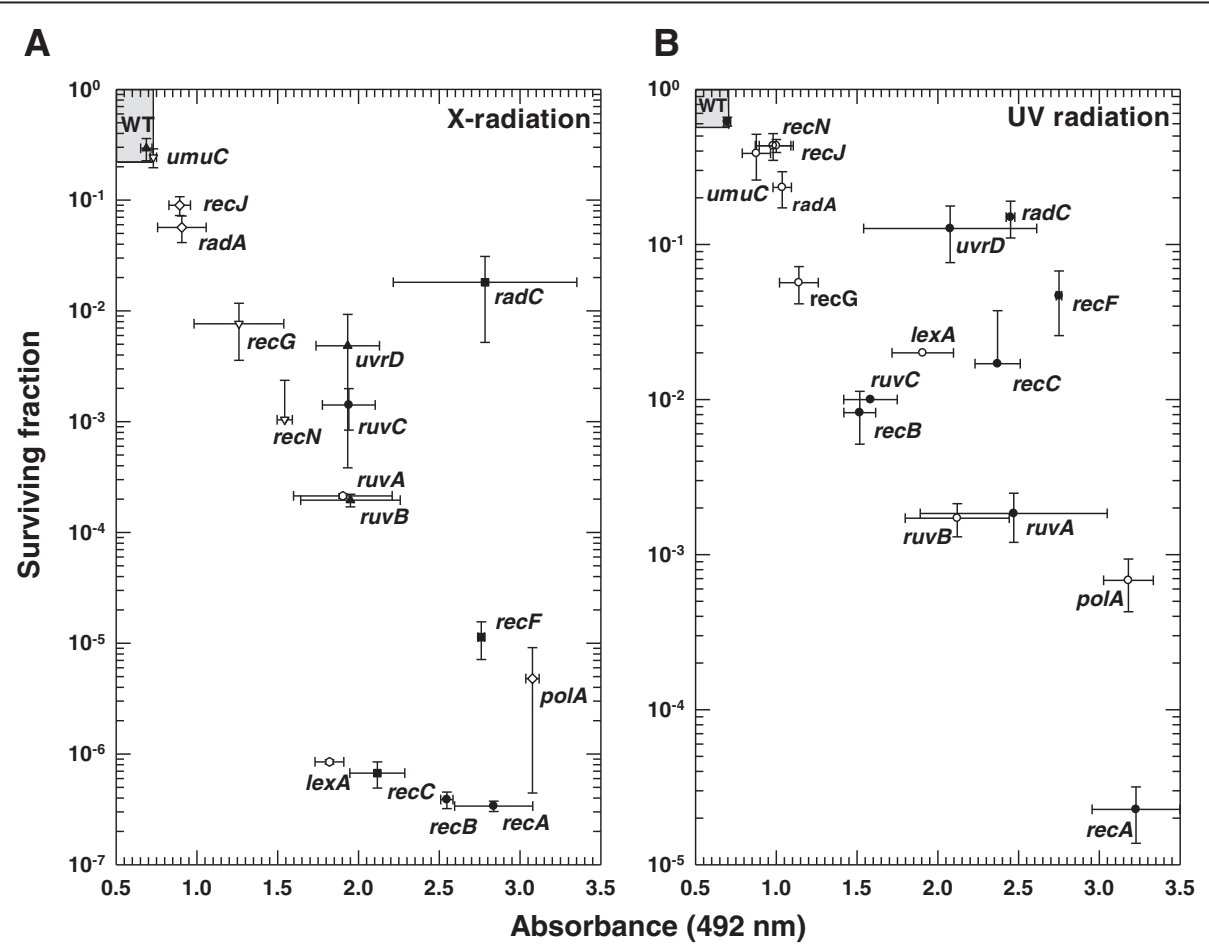

Figure 3 Comparison of colorimetric and clonogenic assays for radiation-sensitive phenotype of $E$. coli reference strains. Mutant strains listed in Table 1 were compared with the isogenic parental control strain (SR749, WT) for recovery from radiation treatment. (A) X-radiation, $250 \mathrm{~Gy}$. (B) UV-radiation, $100 \mathrm{~J} \mathrm{~m}^{-2}$. All data points are means from triplicate experiments. Standard deviations (horizontal bars displaying variation in absorbance values and vertical bars displaying variation in surviving fraction values) are shown. The gray-shaded boxes represent the mean \pm 2 sem for the WT strain. Any strain data points that fall outside of the gray-shaded boxes are significantly different (Kruskal-Wallis one way ANOVA on Ranks, $\mathrm{P}<0.05)$ in their absorbance and surviving fraction values from the WT strain. 
Table 2 Radiation impact on Escherichia coli strains assessed by clonogenic (surviving fraction) and colorimetric (resazurin) assays ${ }^{\mathrm{a}}$

\begin{tabular}{|c|c|c|c|c|}
\hline \multirow{2}{*}{$\begin{array}{l}\text { E. coli K-12 strain } \\
\text { (DNA repair defect) }\end{array}$} & \multicolumn{2}{|c|}{ X-irradiation (250 Gy) } & \multicolumn{2}{|c|}{ UV-irradiation $\left(100 \mathrm{~J} \mathrm{~m}^{-2}\right)$} \\
\hline & Surviving fraction & Resazurin $\mathrm{A}_{492}$ & Surviving fraction & Resazurin $\mathrm{A}_{492}$ \\
\hline SR749 (parental, control) & $2.9( \pm 0.7)$ e-1 & $0.7( \pm 0.04)$ & $6.2( \pm 0.4)$ e- 1 & $0.7( \pm 0.02)$ \\
\hline SR1159 (recB21) & $3.9( \pm 0.7)$ e-7 & $2.6( \pm 0.04)$ & $1.0( \pm 0.0)$ e-2 & $1.6( \pm 0.2)$ \\
\hline SR1 165 (umuC122::Tn5) & $2.4( \pm 0.5)$ e- 1 & $0.7( \pm 0.02)$ & $3.9( \pm 1.3)$ e- 1 & $0.9( \pm 0.09)$ \\
\hline SR1 187 (radC102) & $2.0( \pm 1.0)$ e-2 & $2.8( \pm 0.6)$ & $1.5( \pm 0.4)$ e- 1 & $2.4( \pm 0.03)$ \\
\hline SR1252 (polA5) & $4.8( \pm 4.3)$ e- 6 & $3.1( \pm 0.04)$ & $6.8( \pm 2.5)$ e- 4 & $3.2( \pm 0.2)$ \\
\hline SR1277 (uvrD254::Tn5) & $4.8( \pm 4.5) \mathrm{e}-3$ & $1.9( \pm 0.20)$ & $1.3( \pm 0.5)$ e- 1 & $2.1( \pm 0.5)$ \\
\hline SR1279 (lexA101) & $8.5( \pm 0.4)$ e- 7 & $1.8( \pm 0.09)$ & $2.0( \pm 0.0)$ e- 2 & $1.9( \pm 0.2)$ \\
\hline SR1467 (recA srl301::Tn10) & $3.4( \pm 0.4)$ e-7 & $2.8( \pm 0.2)$ & $2.3( \pm 0.9)$ e- 5 & $3.2( \pm 0.3)$ \\
\hline SR1553 (recN262) & $1.0( \pm 1.3) \mathrm{e}-3$ & $1.5( \pm 0.05)$ & $4.3( \pm 0.9)$ e- 1 & $1.0( \pm 0.1)$ \\
\hline SR1643 (recC22) & $6.7( \pm 1.8)$ e-7 & $2.1( \pm 0.2)$ & $2.0( \pm 2.0) \mathrm{e}-2$ & $2.4( \pm 0.1)$ \\
\hline SR1663 (recJ284::Tn10) & $9.0( \pm 2.0)$ e-2 & $0.9( \pm 0.07)$ & $4.3( \pm 0.4)$ e- 1 & $1.0( \pm 0.1)$ \\
\hline SR2384 (ruvA59::Tn10) & $2.0( \pm 0.3)$ e- 4 & $2.0( \pm 0.3)$ & $1.8( \pm 0.6)$ e-3 & $2.5( \pm 0.6)$ \\
\hline SR2385 (ruvB60::Tn10) & $2.1( \pm 0.09) \mathrm{e}-4$ & $1.9( \pm 0.3)$ & $1.7( \pm 0.4)$ e-3 & $2.1( \pm 0.3)$ \\
\hline SR2603 (AruvC64::kan) & $1.4( \pm 0.6) \mathrm{e}-3$ & $1.9( \pm 0.2)$ & $8.2( \pm 3.1)$ e-3 & $1.5( \pm 0.1)$ \\
\hline SR2604 (recG258::kan) & $7.6( \pm 4.1)$ e-3 & $1.3( \pm 0.3)$ & $6.0( \pm 2.0)$ e-2 & $1.1( \pm 0.2)$ \\
\hline SR2666 (recF332::Tn3) & $1.1( \pm 0.4)$ e -5 & $2.8( \pm 0.02)$ & $5.0( \pm 2.0)$ e-2 & $2.8( \pm 0.02)$ \\
\hline SR2877 (radA110::kan) & $6.0( \pm 2.0) \mathrm{e}-2$ & $0.9( \pm 0.2)$ & $2.3( \pm 0.6) \mathrm{e}-1$ & $1.0( \pm 0.06)$ \\
\hline
\end{tabular}

${ }^{a}$ Data are means ( \pm sd) from triplicate experiments. SR749 (the parental, control strain) is considered a DNA repair proficient strain (Sargentini and Smith 1986) compared to the listed 16 strains derived from it by bacteriophage transduction.

not fall within the shaded box were considered significantly different from the parental, control strain in their $\mathrm{A}_{492}$ values (Kruskal-Wallis one way ANOVA on Ranks: $\mathrm{X}$-radiation $\mathrm{H}=46.891 \mathrm{P}<0.001$, UV-radiation $\mathrm{H}=47.370$ $\mathrm{P}<0.001)$. Under these constraints, only $\mathrm{X}$-irradiated $u m u C$ cells were not different from the control strain, which was verified with a $t$-test $(\mathrm{t}=1.912, \mathrm{P}=0.128)$. These results for $u m u C$ are consistent with published results for $\mathrm{x}$-radiation sensitivity (Sargentini and Smith 1986). In addition, we performed a $t$-test comparing the nearest "sensitive strain", recJ in this case, to the parental control strain to confirm that it was statistically different $(\mathrm{t}=4.874, \mathrm{P}=0.008)$. For $\mathrm{UV}$ radiation, all test strains were significantly different from the parental, control strain and the nearest "sensitive strains" were verified with $t$-tests, umuC $(\mathrm{t}=3.158, \mathrm{P}=0.025)$ and recJ $(\mathrm{t}=4.775, \mathrm{P}=0.009)$. Although the data in Figures $3 \mathrm{~A}$ and $3 \mathrm{~B}$ suggest one could use our colorimetric assay to quantitatively differentiate $E$. coli strains on the basis of their radiation sensitivity, our focus was to develop a screening assay that would allow simple and rapid differentiation of radiation-sensitive strains from a parental, control strain.

We compared our two assays for time and cost (Table 3), and found the colorimetric assay (compared to the clonogenic assay) would save about $\$ 1200$ and 7 days of work per $96 \mathrm{E}$. coli strains tested, without considering technician pay. Therefore, our colorimetric method was superior in terms of man-hours, pipetting steps and expense for supplies when compared to the clonogenic assay.

\section{Conclusions}

In summary, we have described a novel, resazurin-based colorimetric method for high-throughput screening of E. coli strains for radiation sensitivity. This assay is easy to follow, depends on many fewer pipetting steps, is highly economical in terms of man-hours and supplies, and provides results that compare well with standard, more expensive and time-consuming clonogenic assays.

\section{Methods}

X-radiation dose rates were determined for a Polaris Model XR160 cabinet irradiator (Kimtron) using Fricke's dosimetry solution $\left(0.8 \mathrm{~N} \mathrm{H}_{2} \mathrm{SO}_{4}, 1 \mathrm{mM} \mathrm{FeSO} \cdot 7 \mathrm{H}_{2} \mathrm{O}\right.$, $1 \mathrm{mM} \mathrm{NaCl}$ ) (Fricke and Hart 1966). Fricke's solution was placed in a 96-well microtiter plate (Fisherbrand round bottom, Fisher Scientific) at $200 \mu \mathrm{l} /$ well and irradiated for $3 \mathrm{~min}$ at the center of a metal platform $14 \mathrm{~cm}$ below a $3000 \mathrm{~W}$, Varian NDI-161 tube running at $160 \mathrm{kV}$ and $15 \mathrm{~mA}$. The dose rate in each well was determined by measuring the absorbance at $304 \mathrm{~nm}\left(\mathrm{~A}_{304}\right)$ using a biophotometer (Eppendorf). The mean dose rate over the 96 wells of triplicate plates was calculated from $\left(\Delta \mathrm{A}_{304}\right)$ 
Table 3 Cost comparison of clonogenic and colorimetric assays for measuring radiation sensitivity of Escherichia coli strains

\begin{tabular}{|c|c|c|c|}
\hline Unique steps/costs ${ }^{a}$ & $\begin{array}{l}\text { Clonogenic } \\
\text { (surviving fraction) }\end{array}$ & $\begin{array}{l}\text { Colorimetric } \\
\text { (resazurin) }\end{array}$ & $\begin{array}{l}\text { Differential "cost" } \\
\text { (clonogenic minus colorimetric) }\end{array}$ \\
\hline $\begin{array}{l}\text { Reusable vessels for } \\
\text { radiation (UV, X-ray) testing } \\
\text { of } 96 \text { strains: }\end{array}$ & $\begin{array}{l}\text { Cost for } 96,50-\mathrm{ml} \text { centrifuge } \\
\text { tubes (X-ray), } 96 \text { glass Petri dishes } \\
(\mathrm{UV})=\$ 465\end{array}$ & $\begin{array}{l}\text { Cost for } 2 \text { microtiter } \\
\text { plates }=\$ 6 \text { (one-time use only) }\end{array}$ & $\$ 458$ \\
\hline $\begin{array}{l}\text { Irradiation process } \\
\text { (strains testable/day): }\end{array}$ & 20 & 96 & Time, 5 days \\
\hline \multirow[t]{3}{*}{$\begin{array}{l}\text { Post-irradiation incubation } \\
\text { of cell cultures }\end{array}$} & $\begin{array}{l}\text { Prepare dilution blanks using } \\
\text { buffer and reusable glass } \\
\text { vials = } \$ 65 \text { (100 glass vials); time, } 0.5 \mathrm{~h}\end{array}$ & None & $\$ 65 ;$ time, $0.5 \mathrm{~h}$ \\
\hline & $\begin{array}{l}\text { Prep. of agar plates } \$ 225 \\
\text { (for } 500 \text { Petri dishes for plating media); } \\
\text { time, } 1 \text { day }\end{array}$ & None & $\$ 225 ;$ time, 1 day \\
\hline & Plating of bacteria; time, $4 \mathrm{~h}$ & $\begin{array}{l}\text { Adding media to wells; } \\
\text { time, } 1 \mathrm{~h}\end{array}$ & Time, $3 \mathrm{~h}$ \\
\hline $\begin{array}{l}\text { Quantification of radiation } \\
\text { sensitivity: }\end{array}$ & $\begin{array}{l}\text { Counting colonies and calculations; } \\
\text { time, } 4 \mathrm{~h}\end{array}$ & $\begin{array}{l}\text { Read absorbance values of } \\
\text { microtiter plate; time, } 0.25 \mathrm{~h}\end{array}$ & Time, $3.75 \mathrm{~h}$ \\
\hline Pipetting steps (per strain tested): & 6 & 3 & $\begin{array}{l}3 \text { pipetting steps per strain } \\
\text { (i.e., more error) }\end{array}$ \\
\hline
\end{tabular}

${ }^{\text {a }}$ Costs for supplies were calculated from prices listed on the Fisher Scientific website in December 2012.

(280 Gy $\mathrm{min}^{-1}$ ) for $160 \mathrm{kV}$ X-rays (Shalek and Smith 1969) to be $17.96 \mathrm{~Gy} / \mathrm{min}(\mathrm{sd}=0.02)$.

UV radiation was supplied by an $8-\mathrm{W}$ germicidal lamp (GE, G8T5) emitting primarily at $254 \mathrm{~nm}$. The UV radiation dose rate was $1.42 \mathrm{~J} \mathrm{~m}^{-2} \mathrm{~s}^{-1}$ at the base of a microtiter plate (47 $\mathrm{cm}$ below the lamp) using a germicidal photometer (Model IL1700, International Light, Inc.). However, we used a bioassay to test for uniformity of dose rate across the 96 wells of a microtiter plate. For this purpose, E. coli strain SR749 was grown overnight in $5 \mathrm{ml}$ Luria-Bertani (LB) broth (Miller 1972) supplemented with $1 \%$ glucose for $15-17 \mathrm{~h}$ (in a tube roller for aeration) to a stationary-phase cell concentration of $\sim 1 \times 10^{9}$ colony-forming units (CFU) per ml. Cultures were diluted $\sim 15$-fold to an optical density at $600 \mathrm{~nm}\left(\mathrm{OD}_{600}\right)$ of 0.03 (NanoDrop 2000c; Fisher; corresponding to $6.4 \times 10^{7} \mathrm{CFU} / \mathrm{ml}$ ) with $67 \mathrm{M} \mathrm{NaK}$ phosphate buffer (PB). A 50- $\mu$ l cell volume was placed into each well of six 96-well microtiter plates and these were UV-irradiated with a dose of $50 \mathrm{~J} \mathrm{~m}^{-2}$. After irradiation, $150 \mu \mathrm{l}$ of LB and $10 \mu \mathrm{l}$ of $0.675 \%$ resazurin (Difco) solution were added to each well and plates were incubated at $37^{\circ} \mathrm{C}$ for $4.5 \mathrm{~h}$. To compare the UV radiation doses received in each of the 96 wells of the microtiter plates, we determined the development of pink color (related to cell viability) by measuring $\mathrm{A}_{492}$ values (LabSystems MultiSkan MCC/340).

To simultaneously measure radiation sensitivity of E. coli strains by resazurin and clonogenic assays, cells were prepared as above, but 300- $\mu$ l volumes of cell suspensions $\left(\sim 6.4 \times 10^{7} \mathrm{CFU} / \mathrm{ml}\right)$ were placed in wells in two separate 96-well microtiter plates. One plate was X-irradiated (250 Gy), the other was UV irradiated $\left(100 \mathrm{~J} \mathrm{~m}^{-2}\right)$. After irradiation, cells were re-pipetted (3x) and $250 \mu \mathrm{l}$ of cells from each well were removed and saved for the clonogenic assay (along with a sample of non-irradiated cells). The remaining 50- $\mu$ l volume of cells was mixed with $\mathrm{LB} /$ resazurin solution and incubated as above. The incubation time ( $4.5 \mathrm{~h}$ ) was optimized in pilot experiments to consistently be able to visually differentiate cultures of control radiation-resistant strains (bright pink color) from cultures of radiation-sensitive strains (purple color). Once incubation was complete, $\mathrm{A}_{492}$ values were determined as above. Cell surviving fractions of UV- and X-irradiated cells were determined using our clonogenic assay by plating the cells saved from the microtiter plates used in the colorimetric assay. Irradiated or non-irradiated cells were spread onto duplicate LB agar plates, either directly or after dilution in $\mathrm{PB}$. After overnight incubation at $37^{\circ} \mathrm{C}$, colonies were counted to determine the colony forming units per $\mathrm{ml}$ $(\mathrm{CFU} / \mathrm{ml})$ values for the non-irradiated and irradiated cell suspensions. The CFU/ml value for a cell suspension was determined by multiplying the mean number of colonies per plate by the dilution factor. The cell surviving fraction was determined as the ratio of the CFU/ml value after each radiation dose divided by the $\mathrm{CFU} / \mathrm{ml}$ value for nonirradiated (control) cells. Experiments were completed in triplicate to determine the mean surviving fraction $\pm \mathrm{sd}$ for each radiation dose.

Competing interests

The authors declare that they have no competing interests.

\section{Authors' contributions}

NJS and DAH designed the study, DAH performed experiments; DAH collected and analyzed data; NJS provided reagents, supplies and technical support; DAH and NJS wrote and approved the manuscript. 


\section{Acknowledgments}

We thank Jane Johnson, M.S., for statistical guidance and Nicholas Gularte, M. S., for helpful discussions.

Received: 7 December 2012 Accepted: 13 February 2013

Published: 16 February 2013

\section{References}

Augusto-Pinto L, Regis da Silva CG, Lopes Dde O, Machado-Silva A, Machado CR (2003) Escherichia coli as a model system to study DNA repair genes of eukaryotic organisms. Genet Mol Res 2:77-91

Berlyn MK (1998) Linkage map of Escherichia coli K-12, edition 10: the traditional map. Microbiol Mol Biol Rev 62:814-984

Bigalke DL (1984) Methods used for monitoring the microbiological quality of raw milk. Dairy Food Sanit 4:189-190

Drummond AJ, Waigh RD (2000) The development of microbiological methods for phytochemical screening. In: Pandalai S (ed) Recent research developments in phytochemistry. Research Signpost, India

Fricke H, Hart EJ (1966) Chemical dosimetry. In: Attix F, Roesch W (eds) Radiation dosimetry, vol 2. Academic, New York

Friedberg EC, Walker GC, Siede W, Wood RD, Schultz RA, Ellenberger T (2006) DNA repair and mutagenesis, 2nd edn. ASM Press, Washington DC

Gil S, Sarun S, Biete A, Prezado Y, Sabés M (2011) Survival analysis of F98 glioma rat cells following minibeam or broad-beam synchrotron radiation therapy. Radiat Oncol 6:37-46

McNicholl BP, McGrath JW, Quinn JP (2006) Development and application of a resazurin-based biomass activity test for activated sludge plant management. Water Res 41:127-133

Miller JH (1972) Experiments in molecular genetics. Cold Spring Harbor, New York

Sargentini NJ, Smith KC (1986) Quantitation of the involvement of the recA, recB, recC, recF, recJ, recN, lexA, radA, radB, uvrD, and umuC genes in the repair of $X$-ray-induced DNA double-strand breaks in Escherichia coli. Radiat Res 107:58-72

Sarker SD, Nahar L, Kumarasamy Y (2007) Microtitre plate-based antibacterial assay incorporating resazurin as an indicator of cell growth, and its application in the in vitro antibacterial screening of phytochemicals. Methods 42:321-324

Seideman JH, Shum D, Djaballah H, Scheinberg DA (2010) A high-throughput screen for alpha particle radiation protectants. Assay Drug Dev Technol 5:602-614

Shalek RJ, Smith CE (1969) Chemical dosimetry for the measurement of highenergy photons and electrons. Ann N Y Acad Sci 161:44-62

Vega-Avila E, Pugsley MK (2011) An overview of colorimetric assay methods used to assess survival or proliferation of mammalian cells. Proc West Pharmacol Soc 54:10-14

doi:10.1186/2193-1801-2-55

Cite this article as: Hudman and Sargentini: Resazurin-based assay for screening bacteria for radiation sensitivity. SpringerPlus 2013 2:55.

\section{Submit your manuscript to a SpringerOpen ${ }^{\odot}$ journal and benefit from:}

- Convenient online submission

- Rigorous peer review

- Immediate publication on acceptance

- Open access: articles freely available online

- High visibility within the field

- Retaining the copyright to your article

Submit your next manuscript at $\boldsymbol{~ s p r i n g e r o p e n . c o m ~}$ 